\title{
Original article \\ Colour variability of beef in young bulls from fifteen European breeds
}

\author{
Guillermo Ripoll, ${ }^{1 *}$ (D) Pere Albertí, ${ }^{1}$ Begoña Panea, ${ }^{1}$ Sebastiana Failla, ${ }^{2}$ Jean F. Hocquette, ${ }^{3}$ Susana Dunner, ${ }^{4}$ \\ Carlos Sañudo, ${ }^{5}$ José L. Olleta, ${ }^{5}$ Mette Christensen, ${ }^{6}$ Per Ertbjerg, ${ }^{7}$ Ian Richardson, ${ }^{8}$ Serafino Concetti ${ }^{2}$ \& \\ John L. Williams ${ }^{9}$ \\ 1 Centro de Investigación y Tecnología Agroalimentaria de Aragón (CITA), Instituto Agroalimentario de Aragón - IA2 (CITA-Universidad \\ de Zaragoza), Avda, Montañana, 930, Zaragoza 50059, Spain \\ 2 Research Centre for Animal Production and Aquaculture, CREA, Monterotondo 00015, Italy \\ 3 VetAgro Sup, UMR1213, Unité de Recherches sur les Herbivores, Theix, INRA, Saint-Genès Champanelle F-63122, France \\ 4 Departamento de Producción Animal, Facultad de Veterinaria, Universidad Complutense, Madrid 28040, Spain \\ 5 Instituto Agroalimentario de Aragón - IA2 (CITA-Universidad de Zaragoza), Universidad de Zaragoza, Zaragoza 50013, Spain \\ 6 Frontmatec Smoerum A/S, Hassellunden 9, Smoerum, DK-2765, Denmark \\ 7 Department of Food and Environmental Sciences, University of Helsinki, Helsinki, FI-00014, Finland \\ 8 Division of Farm Animal Science, University of Bristol, Bristol, BS40 5DU, UK \\ 9 Davies Research Centre, School of Animal and Veterinary Sciences, University of Adelaide, Roseworthy, SA 5371, Australia
}

(Received 18 April 2018; Accepted in revised form 28 June 2018)

Summary The objective of this study was to determine the variation of the colour of longissimus thoracis muscle within and among fifteen European cattle breeds reared under comparable management conditions. A total of 436 unrelated purebred young bulls from fifteen European breeds (Aberdeen Angus, Highland, Jersey, South Devon, Danish Red, Holstein, Simmental, Asturiana de las Montañas (also known as Casina), Asturiana de los Valles, Avileña-Negra Ibérica, Pirenaica, Marchigiana, Piemontese, Charolais and Limousin) were reared in five experimental research centres in the United Kingdom, Denmark, Spain, Italy and France. The $\mathrm{pH}$ of $\mathrm{M}$. longissimus thoracis was measured at $24 \mathrm{~h}$ and after 10 days of ageing and colour at $48 \mathrm{~h}$ and 10 days. Two generalised linear models, Pearson correlations and a hierarchical cluster analyses were carried out. Lean meat colour differed significantly between breeds, and these fifteen European breeds could be grouped according to four classes of commercial interest: 'very bright and pale-red', 'bright and pale', 'red' and 'dark and dull red'. These groups were partially related to body size and carcass traits, fatness and muscle development and structure, and were controlled by differences in gene expression within each breed.

Keywords Cattle, cluster, colour difference, loin, pH.

\section{Introduction}

Consumer preference and characteristics of meat available in each country or market, determines the level of meat consumption. Colour is a major intrinsic trait that influences the consumer's intention to purchase (Lynch et al., 1986), as they relate colour to freshness and the sensory eating quality. In the Mediterranean European countries, consumers show a preference for pink or pale-red coloured beef, while in the UK or Germany consumers like red meat (Corcoran et al., 2001). However, the colour of fresh meat is not well correlated with the eating quality (Taylor, 1996). To

*Correspondent: Fax: +34 976716 335; e-mail: gripoll@aragon.es evaluate colour is a complex task because meat colour evaluation is a subjective assessment. Meat colour is affected by several factors, including breed and $\mathrm{pH}$ (Ripoll et al., 2012). The relation between meat colour and $\mathrm{pH}$ is widely accepted, especially the effect on $\mathrm{b}^{*}$ and hue angle of beef (Mancini \& Hunt, 2005). A large number of genetically distinct cattle breeds exist in Western Europe and this genetic diversity produces meat with many different quality traits (Albertí et al., 2008). In the European market, beef carcasses are valued on the basis of animal category (bull, steer, heifer, cow), carcass weight and the European carcass classification scores which is based on conformation and fat cover (E.U., 2008). However, this assessment has no 
relationship with the eating quality of beef (Bonny et al., 2016). New indicators have been proposed to improve the SEUROP classification such as meat colour (Monteils et al., 2017). Today, measurement of meat colour is not compulsory, and in the voluntary labelling (E.U., 2000) of colour assessment is subjective using colour reference standards. Many studies have found significant differences between breeds in colour traits, but the difficulty arises when the CIELab have to be interpreted as commercial colour differences. The present study examines variation of the colour of longissimus thoracis muscle within and among fifteen European cattle breeds reared under comparable management conditions.

\section{Material and methods}

\section{Animal and rearing conditions}

All procedures were approved by the in-house Ethics Committee for Animal Experiments of each participating research centres. The care and use of animals were in accordance with the European Union Directive $2010 / 63$ on the protection of animals used for experimental and other scientific purposes (E.U., 2010).

A total of 436 unrelated pure breed young bulls from fifteen European breeds were reared in five experimental research centres in the United Kingdom, Denmark, Spain, Italy and France. The breeds included in the study were: Aberdeen Angus, Highland, Jersey, South Devon, Danish Red, Holstein, Simmental, Asturiana de las Montañas (also known as Casina), Asturiana de los Valles, Avileña-Negra Ibérica, Pirenaica Marchigiana, Piemontese, Charolais and Limousin. The number of animals per breed is shown in Table 1. Animals were selected to be as unrelated as possible to ensure that the full range of genetic diversity present within breeds was included in the study.

A uniform beef management system, representative of those used in European Union countries, was used for all breeds to homogenise as far as possible the influence of management and rearing systems on meat quality. All the animals were transported to the experimental farms at 9 months of age. Then, they were divided into groups of seven to eight animals and fed a standardised diet. The diet consisted of a concentrate compounded from barley flakes $(80-84 \%)$, soya bean meal $(7.5-11 \%)$ sodium bicarbonate $(0.6 \%)$ with suitable vitamin supplements $(1.5 \%)$ and barley straw, all fed ad libitum. The energy density ratio ranged from 12.9 to $13.5 \mathrm{ME} / \mathrm{kgDM}$. The protein content was $160 \mathrm{~g} \mathrm{CP} / \mathrm{kgDM}$ up to 10 months of age and then decreased to $150 \mathrm{~g} \mathrm{CP} / \mathrm{kg} \mathrm{DM}$ to slaughter. The space available to the animals was approximately $9 \mathrm{~m}^{2}$ per animal. Performances, body size and carcass
Table 1 Number of animals, slaughter weight and age, and $\mathrm{pH}$ at 10 days from fifteen European young bulls breeds

\begin{tabular}{|c|c|c|c|c|}
\hline Breed & $n$ & $\begin{array}{l}\text { Slaughter } \\
\text { weight }(\mathbf{k g})\end{array}$ & $\begin{array}{l}\text { Slaughter } \\
\text { age (d) }\end{array}$ & pH 10 days \\
\hline $\begin{array}{l}\text { Aberdeen } \\
\text { Angus }\end{array}$ & 30 & $597.7 \pm 4.6^{\mathrm{bcd}}$ & $428.6 \pm 8.8^{\mathrm{cd}}$ & $5.63 \pm 0.01^{\mathrm{abcd}}$ \\
\hline $\begin{array}{l}\text { Asturiana de } \\
\text { los Valles }\end{array}$ & 30 & $557.7 \pm 8.8^{\mathrm{ef}}$ & $460.6 \pm 5.5^{b}$ & $5.57 \pm 0.01^{\text {bcde }}$ \\
\hline $\begin{array}{l}\text { Avileña-Negra } \\
\text { Ibérica }\end{array}$ & 30 & $550.9 \pm 13.4^{\mathrm{efg}}$ & $462.2 \pm 6.3^{b}$ & $5.57 \pm 0.01^{\text {bcde }}$ \\
\hline Casina & 31 & $443.5 \pm 7.1^{\mathrm{h}}$ & $461.4 \pm 4.7^{b}$ & $5.59 \pm 0.01^{\mathrm{abcd}}$ \\
\hline Charolais & 30 & $634.0 \pm 7.3^{\mathrm{a}}$ & $460.6 \pm 3.9^{b}$ & $5.57 \pm 0.01^{\text {bcde }}$ \\
\hline Danish Red & 29 & $580.0 \pm 10.6^{\mathrm{cde}}$ & $454.3 \pm 2.8^{b}$ & $5.58 \pm 0.01^{\mathrm{abcd}}$ \\
\hline Highland & 29 & $443.5 \pm 3.4^{\mathrm{h}}$ & $510.6 \pm 8.9^{a}$ & $5.65 \pm 0.02^{\mathrm{abc}}$ \\
\hline Holstein & 29 & $596.3 \pm 9.3^{\mathrm{bcd}}$ & $458.0 \pm 1.0^{\mathrm{b}}$ & $5.64 \pm 0.03^{\mathrm{abc}}$ \\
\hline Jersey & 31 & $378.4 \pm 1.5^{\mathrm{i}}$ & $414.7 \pm 6.4^{\mathrm{de}}$ & $5.68 \pm 0.02^{\mathrm{ab}}$ \\
\hline Limousin & 31 & $565.4 \pm 5.4^{\mathrm{ed}}$ & $428.0 \pm 4.1^{\mathrm{cd}}$ & $5.56 \pm 0.01^{\text {cde }}$ \\
\hline Marchigiana & 28 & $523.5 \pm 7.2^{\mathrm{g}}$ & $459.2 \pm 3.7^{b}$ & $5.52 \pm 0.01^{\mathrm{de}}$ \\
\hline Piemontese & 30 & $527.3 \pm 7.3^{\mathrm{fg}}$ & $461.0 \pm 3.5^{b c}$ & $5.51 \pm 0.01^{\mathrm{e}}$ \\
\hline Pirenaica & 31 & $602.4 \pm 9.5^{\mathrm{abc}}$ & $444.8 \pm 5.8^{b c}$ & $5.54 \pm 0.01^{\text {cde }}$ \\
\hline Simmental & 20 & $621.8 \pm 20.9^{\mathrm{ab}}$ & $455.9 \pm 2.4^{\mathrm{b}}$ & $5.69 \pm 0.03^{\mathrm{a}}$ \\
\hline South Devon & 27 & $591.7 \pm 6.2^{\mathrm{bcd}}$ & $398.5 \pm 9.0^{\mathrm{e}}$ & $5.60 \pm 0.01^{\mathrm{abcd}}$ \\
\hline
\end{tabular}

Means \pm standard error.

Different lowercase letter in the same column implies statistical differences between breeds $(P<0.05)$.

characteristics of the fifteen breeds were reported by Albertí et al. (2008).

\section{Sampling and measurements}

At approximately $75 \%$ mature bull weight, animals were slaughtered by captive bolt pistol and exsanguination in either commercial or experimental slaughterhouses, depending on the experimental facilities of each country. Carcass dressing followed a standardised project protocol without use of electrical stimulation. The carcasses were chilled at $4{ }^{\circ} \mathrm{C}$ for $24 \mathrm{~h}$, then the M. longissimus thoracis (LT) muscle was excised from the left side of the carcass between the 6th and the 13th rib and $\mathrm{pH}\left(\mathrm{pH}_{24}\right)$ was measured on LT. The LT was vacuum packed and aged at $2{ }^{\circ} \mathrm{C} \pm 1{ }^{\circ} \mathrm{C}$ until $48 \mathrm{~h}$ post-mortem. Then, a $3.5 \mathrm{~cm}$ thick sample was sliced from around the position of the 8th vertebra, vacuum packed and frozen at $-18{ }^{\circ} \mathrm{C}$ until colour determination (colour at $48 \mathrm{~h}$ ). The remaining section of the LT was vacuum packed and stored in the dark at $2{ }^{\circ} \mathrm{C} \pm 1{ }^{\circ} \mathrm{C}$ until 10 days post-mortem. Then, one $3.5-\mathrm{cm}$ thick sample at the 10 th vertebra was sliced, vacuum packed and frozen at $-18{ }^{\circ} \mathrm{C}$ for colour determination (colour at 10 days). Meat samples for colour determination from each country were transported on dry ice to the CREA-ZA (Italy).

Samples aged for $48 \mathrm{~h}$ and 10 days were thawed for $24 \mathrm{~h}$, the bag was opened and the $\mathrm{pH}\left(\mathrm{pH}_{10}\right)$ was 
determined using a Hanna HI98240 pH-meter (Hanna Instruments Italia, Padova, Italy). A layer of superficial muscle was removed and each sample placed on a tray, overwrapped with film permeable to oxygen and maintained for one hour in the refrigerator at $4{ }^{\circ} \mathrm{C}$ to allow the myoglobin to bloom. Afterward, LT colour was measured using a Minolta CM-2006 d spectrophotometer (Konica Minolta Holdings Inc.,Tokyo, Japan) in the CIELAB space (CIE, 1986) with a measured area diameter of $8 \mathrm{~mm}$, including a specular component, $0 \%$ u.v. and a standard illuminant D65, which simulated daylight (colour temperature $6504 \mathrm{~K}$ ) and an observer angle of $10^{\circ}$. The integrating sphere had a $52 \mathrm{~mm}$ diameter and the measurement area was covered with a CM-A149 dust cover. Zero and white calibrations were made with the cover. The lightness $\left(\mathrm{L}^{*}\right)$, redness $\left(\mathrm{a}^{*}\right)$ and yellowness $\left(\mathrm{b}^{*}\right)$ were recorded, and the hue angle $\left(h_{a b}\right)$ and chroma $\left(C_{a b}^{*}\right)$ indexes were calculated as $C_{a b}^{*}=\sqrt{(a *)^{2}+(b *)^{2}}$ and $h_{a b}=$ $\tan ^{-1}\left(\frac{b *}{a *}\right) \cdot \frac{180^{\circ}}{\pi}$. Reflectance spectra were recorded from 360 to $740 \mathrm{~nm}$. The colour differences between two breeds $\left(\Delta E^{*}\right)$ were calculated as $\Delta \mathrm{E}^{*}=\sqrt[2]{\left(L_{x t}^{*}-L_{y t}^{*}\right)^{2}+\left(a_{x t}^{*}-a_{y t}^{*}\right)^{2}+\left(b_{x t}^{*}-b_{y t}^{*}\right)^{2}}$, where ' $\mathrm{x}$ ' and ' $\mathrm{y}$ ' are the different breeds and ' $t$ ' is the ageing time ( $48 \mathrm{~h}$ or 10 days). The relative percentage of metmyoglobin were calculated as:

$$
\% \mathrm{MMb}=\left\{1.395-\left[\frac{\langle A 572-A 730\rangle}{\langle A 525-A 730\rangle}\right]\right\} \cdot 100
$$

where $A=\log \frac{1}{R}$. $\mathrm{R}$ is the reflectance at specific wavelength expressed as a decimal. The $C_{a b}^{*}, h_{a b}, \Delta E^{*}$ and $\% \mathrm{MMb}$ were calculated following the calculations detailed in AMSA (2012).

\section{Statistical analysis}

The $\mathrm{pH}_{10}$ values were analysed using the GLM procedure, with breed as fixed effect and the Bonferroni multiple-comparison procedure at $\alpha=0.01$ was used to test significance of differences among breeds. As colour variation at $48 \mathrm{~h}$ and at 10 days were closely correlated, a GLM procedure was carried out with the five colorimetric variables $\left(\mathrm{L}^{*}, \mathrm{a}^{*}, \mathrm{~b}^{*}, C_{a b}^{*}, h_{a b}\right)$ measured at $48 \mathrm{~h}$ only, with breed as fixed effect and using the $\mathrm{pH}_{10}$ as covariate. Differences among least squares means were evaluated with the pdiff option with $\alpha=0.01$. To study relationships between $\mathrm{pH}$ and colour variables, Pearson correlation coefficients between colour variables and $\mathrm{pH}_{24}, \mathrm{pH}_{48}$ and $\mathrm{pH}_{10}$ were determined. In addition, a principal components analysis (PCA) was performed using $\mathrm{L}^{*}, C_{a b}^{*}, h_{a b}, \mathrm{pH}_{24}$ and $\mathrm{pH}_{10}$. A VARIMAX rotation was applied to the retained components to redistribute the variance among factors to obtain factor pattern coefficients.
The inclusion of $\mathrm{pH}_{24}$ and $\mathrm{pH}_{10}$ was checked, either separately or both together. When the $\mathrm{pH}$ at both times was included, the $\mathrm{pH}_{10}$ was retained in the second factor, negatively, and in the third factor, positively. However, $\mathrm{pH}_{24}$ was not retained in the factors with eigenvalues $>1$. Therefore, $\mathrm{pH}_{10}$ was used as it explained a higher percentage of variance.

A hierarchical cluster analysis (Ward's method for aggregation and Euclidian distance) using the matrix of $\Delta \mathrm{E}^{*}$ at $48 \mathrm{~h}$ and 10 days was performed to identify homogeneous groups of breeds. The clusters were established to maximise the intergroup variability and minimise the intragroup variability. The inter- and intra-class variabilities of the clusters of meat colour at $48 \mathrm{~h}$ were $83.4 \%$ and $16.67 \%$, respectively. However, when the colour at 10 days was used the inter- and intra-class variability of the clusters were $74.2 \%$ and $25.8 \%$, respectively. As the inter-class variability was greater, and the intra-class lower, for the clusters using colour at $48 \mathrm{~h}$ than at 10 days, only the dendrogram of colour similarity at $48 \mathrm{~h}$ between breeds was drawn. In addition, the five colorimetric variables $\left(\mathrm{L}^{*}, \mathrm{a}^{*}, \mathrm{~b}^{*}\right.$, $\left.C_{a b}^{*}, h_{a b}\right)$ of meat aged for $48 \mathrm{~h}$ were analysed with the GLM procedure with the cluster as fixed effect using the Bonferroni test with $\alpha=0.01$ to compare means. Statistical analyses were carried out using the SAS statistical package v.9.3 software (SAS Institute Inc., Cary, NC, USA) except for the cluster analysis, which was carried out using the XLSTAT statistical package v.3.05 (Addinsoft, New York, NY, USA).

\section{Results and discussion}

Considerable variation was observed among the fifteen breeds for slaughter weight (Table 1). As it was studied by Albertí et al. (2008), this study underlines the large differences seen between dairy breeds and specialised beef breeds as well among local breeds, which were reflected in the studied traits. Regarding the $\mathrm{pH}$, the $\mathrm{pH}_{24}$ was associated with the breed and ranged from an average of 5.57-5.82. Values of $\mathrm{pH}_{24}$ for each breed are available on Christensen et al. (2011). On average, $\mathrm{pH}_{10}$ was 0.06 units lower than $\mathrm{pH}_{24}$ and both $\mathrm{pH}$ values were correlated with each other $(r=0.43 ; P<0.0001)$. Average values of $\mathrm{pH}_{10}$ (Table 1) ranged from 5.51 to 5.69 which are in the expected range for beef. These results are in accordance with average values reported previously, for example, 5.53 for Charolais (Renand et al., 2001), 5.57 for Simmental and 5.54 for Angus (Chambaz et al., 2003), 5.63 for Holstein (Barahona et al., 2016) and an overall mean of 5.67 for carcasses of different cattle breeds, class and sexes in the Spanish market (Mach et al., 2008).

The $\mathrm{pH}_{10}$ differed significantly among breeds $(P<0.001)$. The animal temperament and the management prior to slaughter are known to affect stress and 
energy reserves in the meat that will affect ultimate $\mathrm{pH}$ (Miranda-de la Lama et al., 2013). Differences in genetic susceptibility to stress among breeds are well known (Miranda-de la Lama et al., 2013). In particular, animals with muscular hypertrophy having a more excitable temperament and are more prone to stress than non-hypertrophic animals (Oliván et al., 2004). A negative correlation between $\mathrm{pH}$ at $48 \mathrm{~h}$ post-mortem and EUROP conformation score has been reported (Klont et al., 1999). Values of conformation for each breed are available on Albertí et al. (2008). In the present study, a Pearson correlation of $r=-0.27$ $(P<0.001)$ was found between conformation score (Conformation score of the fifteen breeds were reported by Albertí et al. (2008)). and $\mathrm{pH}_{10}$, which may partially explain $\mathrm{pH}$ differences between breeds. Ambient temperature influences the rate of $\mathrm{pH}$ fall (Maher et al., 2004), which depends on abattoir cold room settings (Klont et al., 1999). As experimental animals were slaughtered in different slaughterhouses, the ambient temperatures may have differed and in some cases ultimate $\mathrm{pH}$ may not have been reached in $48 \mathrm{~h}$. The intra-breed variation was largest in Simmental, Holstein, Highland and Jersey than in the other breeds. On average, standard error of $\mathrm{pH}$ values reported in the present paper was lower than those reported some other authors (Renand et al., 2001; Maher et al., 2004) but are similar to those for animals raised and slaughtered under controlled conditions (Chambaz et al., 2003; Serra et al., 2004). Intra-breed variability is of interest for breeders who are seeking a recognisable brand, as they have to offer a homogeneous product to the market (Panea et al., 2008). Regarding the relation between $\mathrm{pH}$ and colour, a negative correlation was found between both $\mathrm{pH}_{24}$ and $\mathrm{pH}_{10}$ with colour traits at $48 \mathrm{~h}$ and 10 days (Table 2), with $\mathrm{pH}_{10}$ having higher coefficients of correlation than $\mathrm{pH}_{24}$. It is known that ultimate $\mathrm{pH}$ is not reached in the lighter carcasses by $24 \mathrm{~h}$ post-mortem.

\section{Colour variables: principal component analysis, means and clustering}

The principal component analysis is shown in Fig. 1. The first factor accounted for $47.2 \%$ of the variance and was explained mainly by lightness and $h_{a b}$ values at $48 \mathrm{~h}$ and 10 days. The breeds (South Devon, Aberdeen Angus, Danish Red, Limousin, Asturiana de los Valles, Charolais, Piemontese and Marchigiana) had lighter and paler meat compared with the other breeds found towards the left side. The second factor accounted for $28.1 \%$ of the variance and was explained negatively by $\mathrm{pH}_{10}$ and positively by $C_{a b}^{*}$. Jersey, Simmental, Holstein and Highland breeds had the highest $\mathrm{pH}$ values and were found close together $\left(\mathrm{pH}_{10}\right.$ on axis 2 in Fig. 1)
Table 2 Pearson correlation coefficient and $\mathrm{p}$ values between $\mathrm{pH}$ at $24 \mathrm{~h}$ or $\mathrm{pH}$ at 10 days and colour variables from fifteen European young bulls breeds

\begin{tabular}{|c|c|c|c|c|}
\hline & \multicolumn{2}{|l|}{ pH 24 h } & \multicolumn{2}{|l|}{ pH 10 days } \\
\hline & Coefficient & $P$-value & Coefficient & $P$-value \\
\hline \multicolumn{5}{|c|}{ Colour at $48 \mathrm{~h}$} \\
\hline$L^{*}$ & -0.212 & 0.0001 & -0.461 & 0.0001 \\
\hline$a^{*}$ & -0.091 & 0.06 & -0.192 & 0.0001 \\
\hline$b^{*}$ & -0.246 & 0.0001 & -0.480 & 0.0001 \\
\hline$C_{a b}^{*}$ & -0.174 & 0.0003 & -0.355 & 0.0001 \\
\hline$h_{a b}$ & -0.108 & 0.03 & -0.208 & 0.0001 \\
\hline$\% \mathrm{MMb}$ & -0.023 & 0.64 & -0.136 & 0.005 \\
\hline \multicolumn{5}{|c|}{ Colour at 10 days } \\
\hline $\mathrm{L}^{*}$ & -0.260 & 0.0001 & -0.461 & 0.0001 \\
\hline$a^{*}$ & 0.019 & 0.69 & -0.228 & 0.0001 \\
\hline$b^{*}$ & -0.187 & 0.0001 & -0.510 & 0.0001 \\
\hline$C_{a b}^{*}$ & -0.071 & 0.15 & -0.385 & 0.0001 \\
\hline$h_{a b}$ & -0.193 & 0.0001 & -0.202 & 0.0001 \\
\hline$\% \mathrm{MMb}^{*}$ & -0.007 & 0.89 & 0.002 & 0.96 \\
\hline
\end{tabular}

*\%MMb, Percentage of metmyoglobin.

while Marchigiana and Piemontese breeds, which had low $\mathrm{pH}$ values formed a separate group (opposite side of Fig. 1). Pirenaica and Holstein were projected at opposite positions on axis 2 because the greater $C_{a b}^{*}$ of Pirenaica than Holstein. Highland, Simmental, Holstein, Aberdeen Angus, Red Danish and South Devon had lower $C_{a b}^{*}$ values than the other breeds. Beef with lightness values $>38$ are bright, whereas beef with $C_{a b}^{*}$ around 20 have a vivid red colour (MacDougall, 1982). Casina, Avileña-negra Ibérica, Pirenaica, Asturiana de los Valles, Marchigiana, Piemontese, Charolais and Limousin, which are found on the upper part of the biplot had a more vivid colour $\left(C_{a b}^{*}>20\right)$ while Highland, Simmental, Holstein, Aberdeen Angus, Red Cattle, Jersey and South Devon, at the lower part of the plot had a dull colour $\left(C_{a b}^{*}<20\right)$. Overall the meat of the breeds studied ranged between pale to dark red in colour (Albertí et al., 2017).

Colour variables at $48 \mathrm{~h}$ and 10 days are highly correlated $(P<0.0001)$, with highest correlation coefficients for lightness $(r=0.77)$ and $h_{a b}(r=0.73)$, and medium correlation coefficients for $C_{a b}^{*}(r=0.42)$, redness $(r=0.48)$, yellowness $(r=0.54)$ and metmyoglobin percentage $(r=0.48)$. In consequence, Table 3 shows values for colour variables measured at $48 \mathrm{~h}$ post-mortem only. Values for all variables are in the range reported by other authors (Oliván et al., 2004; Serra et al., 2004). Intra-breed variability was, in general, similar to those reported by Chambaz et al. (2003) ( $\mathrm{SE}=0.4$, in average) or Serra et al. (2004) ( $\mathrm{SE}=0.4$, in average). Panea et al. (2008) reported that the $\mathrm{L}^{*}$ of the muscle of Pirenaica was less variable than $a^{*}$ or $b^{*}$, and muscle $b^{*}$ had a coefficient of variation that was nearly twice that of $a^{*}$. 
Figure 1 Biplot of the principal component analysis of colour and $\mathrm{pH}$ from fifteen European young bulls breeds.

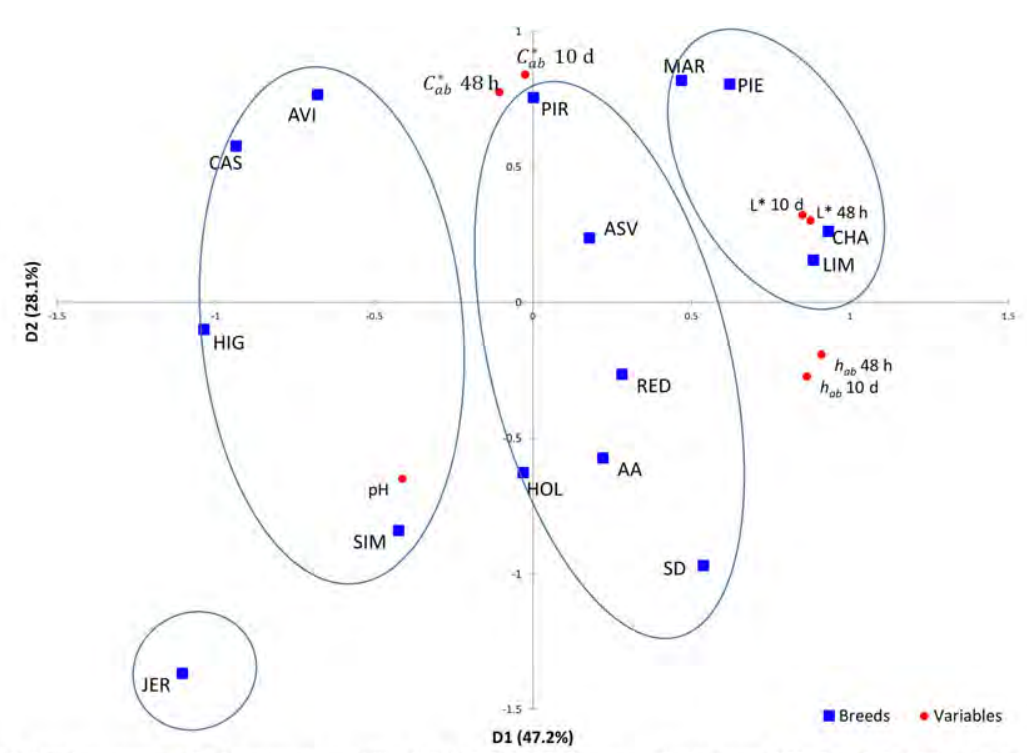

AA: Aberdeen Angus; ASV: Asturiana de los Valles; AVI: Avileña; CAS: Casina; CHA: Charolais; RED: Danish Red; HIG: Highland; HOL: Holstein; JER: Jersey; LIM: Limousin; MAR: Marchigiana; PIE: Piemontese; PIR: Pirenaica; SIM: Simmental; SD: South Devon; $L^{*}$ : lightness; $C_{a b}^{*}$ : chroma; $h_{a b}$ : hue angle; $\mathrm{pH}: \mathrm{pH}$ at 10 days.
Breed affected all colour traits (Table 3). Muscle colour at $48 \mathrm{~h}$ of Jersey, Highland, Casina, Simmental, and Avileña-Negra Ibérica breeds had lower L* and $h_{a b}$ than Charolais, Piemontese, Limousin, and Marchigiana. South Devon and Holstein had the lowest metmyoglobin percentage $(\leq 25 \%)$ while Charolais, Avileña and Casina presented the highest $(\geq 31 \%)$. Breed effect on some colour variables have been widely described in literature, especially for $\mathrm{L}^{*}$ (Gil et al., 2001; Oliván et al., 2004), but also for both $\mathrm{L}^{*}$ and $\mathrm{a}^{*}$ (Cuvelier et al., 2006). Differences in $\mathrm{L}^{*}$ between
Angus, Simmental, Charolais and Limousin steers which were slaughtered at the same intramuscular fat content have been reported (Chambaz et al., 2003). These authors concluded that when animals were slaughtered at the same percentage of adult live weight, differences between breeds were even higher than when animals were slaughtered at the same age, given that some breeds are early- and others latematuring. In the present study, all the animals were slaughtered at approximately the same percentage of mature live weight to minimise differences due to

Table 3 M. longissimus thoracis colour and percentage of metmyoglobin of meat aged $48 \mathrm{~h}$ from fifteen European young bulls breeds

\begin{tabular}{|c|c|c|c|c|c|c|}
\hline Breed & $L^{*}$ & $a^{*}$ & $\mathbf{b}^{*}$ & $C_{a b}^{*}$ & $h_{a b}$ & $\% \mathrm{MMb}$ \\
\hline Aberdeen Angus & $39.8 \pm 0.46^{\mathrm{cd}}$ & $15.3 \pm 0.40^{\mathrm{cde}}$ & $14.3 \pm 0.25^{\mathrm{a}}$ & $21.0 \pm 0.40^{\mathrm{ab}}$ & $43.6 \pm 0.67^{\text {bcde }}$ & $27.3 \pm 0.54^{f}$ \\
\hline Asturiana de los Valles & $40.4 \pm 0.46^{c}$ & $14.5 \pm 0.39^{\text {defg }}$ & $13.6 \pm 0.24^{\mathrm{abc}}$ & $20.0 \pm 0.40^{\mathrm{bcd}}$ & $43.1 \pm 0.67^{\text {cdef }}$ & $28.4 \pm 0.54^{\text {def }}$ \\
\hline Avileña-Negra Ibérica & $38.2 \pm 0.46^{\mathrm{de}}$ & $16.4 \pm 0.39^{\mathrm{abc}}$ & $13.3 \pm 0.24^{\mathrm{c}}$ & $21.1 \pm 0.4 .0^{\mathrm{ab}}$ & $38.8 \pm 0.66^{\mathrm{gh}}$ & $31.2 \pm 0.54^{\mathrm{ab}}$ \\
\hline Casina & $37.3 \pm 0.45^{\mathrm{e}}$ & $17.1 \pm 0.39^{\mathrm{a}}$ & $13.10 .24^{\mathrm{c}}$ & $21.60 .39^{\mathrm{ab}}$ & $37.5 \pm 0.65^{\mathrm{h}}$ & $31.0 \pm 0.53^{\mathrm{ab}}$ \\
\hline Charolais & $42.8 \pm 0.45^{\mathrm{a}}$ & $13.3 \pm 0.39^{i}$ & $13.8 \pm 0.24^{\mathrm{abc}}$ & $19.2 \pm 0.39^{d}$ & $46.2 \pm 0.65^{\mathrm{a}}$ & $31.8 \pm 0.53^{\mathrm{a}}$ \\
\hline Danish Red & $40.5 \pm 0.47^{\mathrm{bc}}$ & $13.9 \pm 0.40^{\mathrm{efg}}$ & $13.3 \pm 0.25^{\mathrm{bcde}}$ & $19.3 \pm 0.41^{\mathrm{d}}$ & $44.1 \pm 0.67^{\mathrm{abcd}}$ & $27.9 \pm 0.54^{\text {def }}$ \\
\hline Highland & $36.9 \pm 0.48^{\mathrm{e}}$ & $16.9 \pm 0.41^{\mathrm{ab}}$ & $13.5 \pm 0.25^{\mathrm{abc}}$ & $21.7 \pm 0.41^{\mathrm{a}}$ & $38.5 \pm 0.68^{g h}$ & $29.4 \pm 0.55^{\mathrm{bcde}}$ \\
\hline Holstein & $39.6 \pm 0.47^{\mathrm{cd}}$ & $14.8 \pm 0.40^{\text {defg }}$ & $13.7 \pm 0.25^{\mathrm{abc}}$ & $20.2 \pm 0.41^{\mathrm{bcd}}$ & $43.1 \pm 0.68^{\text {cdef }}$ & $25.0 \pm 0.55^{\mathrm{g}}$ \\
\hline Jersey & $34.4 \pm 0.47^{f}$ & $13.5 \pm 0.40^{f}$ & $10.5 \pm 0.25^{d}$ & $17.1 \pm 0.41^{\mathrm{e}}$ & $37.7 \pm 0.68^{\mathrm{h}}$ & $29.9 \pm 0.55^{\mathrm{bcd}}$ \\
\hline Limousin & $42.5 \pm 0.46^{\mathrm{a}}$ & $13.6 \pm 0.39^{\mathrm{fg}}$ & $14.0 \pm 0.24^{\mathrm{abc}}$ & $19.5 \pm 0.40^{\mathrm{cd}}$ & $45.8 \pm 0.66^{\mathrm{abc}}$ & $30.8 \pm 0.53^{\mathrm{abc}}$ \\
\hline Marchigiana & $41.2 \pm 0.49^{\mathrm{abc}}$ & $15.6 \pm 0.42^{\mathrm{bcd}}$ & $13.8 \pm 0.26^{\mathrm{abc}}$ & $20.8 \pm 0.42^{\mathrm{abc}}$ & $41.5 \pm 0.70^{\text {efd }}$ & $28.5 \pm 0.57^{\text {def }}$ \\
\hline Piemontese & $42.2 \pm 0.48^{\mathrm{ab}}$ & $15.5 \pm 0.41^{\mathrm{bcd}}$ & $14.2 \pm 0.25^{\mathrm{ab}}$ & $21.1 \pm 0.41^{\mathrm{ab}}$ & $42.5 \pm 0.69^{\text {def }}$ & $29.0 \pm 0.55^{\text {cdef }}$ \\
\hline Pirenaica & $39.6 \pm 0.46^{\mathrm{cd}}$ & $15.8 \pm 0.39^{\mathrm{abcd}}$ & $13.2 \pm 0.24^{\mathrm{abc}}$ & $21.0 \pm 0.40^{\mathrm{ab}}$ & $41.0 \pm 0.66^{\mathrm{fg}}$ & $29.7 \pm 0.53^{\text {bcde }}$ \\
\hline Simmental & $37.9 \pm 0.58^{\mathrm{de}}$ & $15.0 \pm 0.50^{\text {acdef }}$ & $13.0 \pm 0.31^{\mathrm{c}}$ & $19.9 \pm 0.51^{\mathrm{bcd}}$ & $41.2 \pm 0.84^{\mathrm{efg}}$ & $27.6 \pm 0.68^{\text {ef }}$ \\
\hline South Devon & $39.8 \pm 0.49^{\mathrm{cd}}$ & $13.6 \pm 0.41^{\mathrm{gh}}$ & $13.7 \pm 0.26^{\mathrm{abc}}$ & $19.4 \pm 0.42^{\mathrm{cd}}$ & $45.3 \pm 0.70^{\mathrm{abc}}$ & $24.7 \pm 0.56^{\mathrm{g}}$ \\
\hline
\end{tabular}

Least square means \pm standard error. Data were analysed by variance analysis with $\mathrm{pH}$ at 10 days as covariate.

Different lowercase letter in the same column implies statistical differences between breeds $(P<0.05)$. 


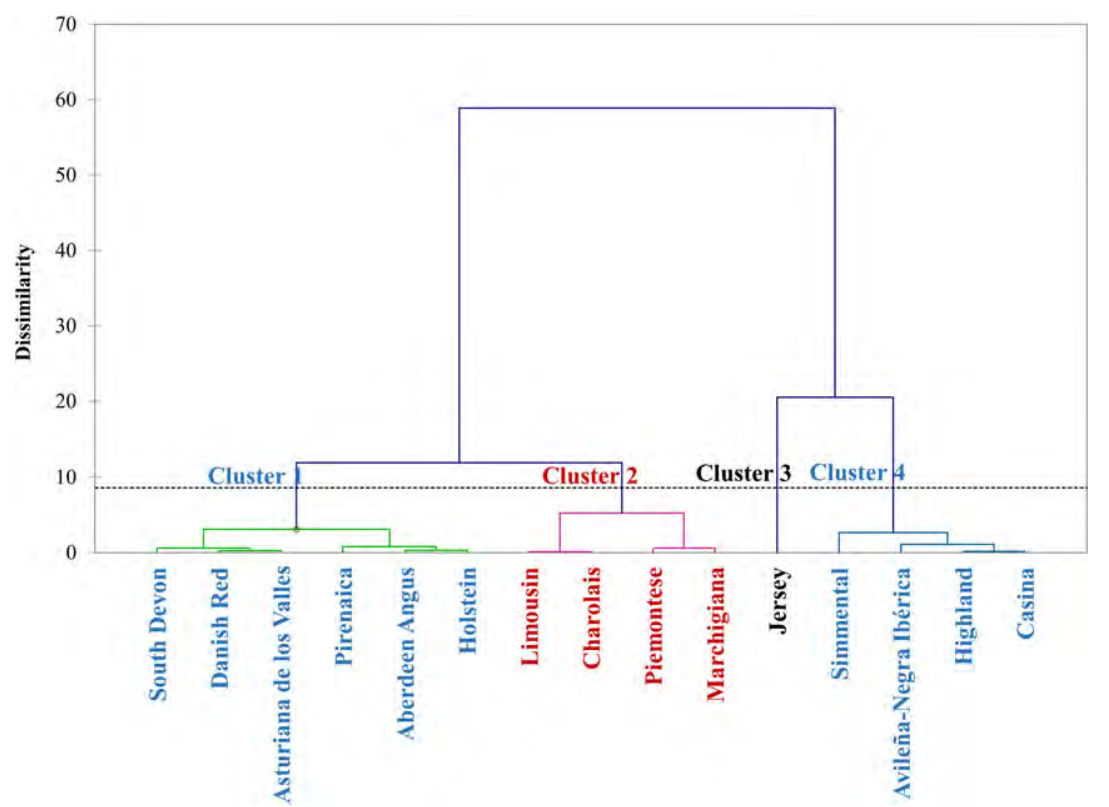

\begin{tabular}{llllll}
\hline & $\mathbf{L}^{*}$ & $\mathbf{a}^{*}$ & $\mathbf{b}^{*}$ & $\boldsymbol{C}_{a b}^{*}$ & $\boldsymbol{h}_{a b}$ \\
\hline Cluster 1 & $39.9 \pm 0.21^{\mathrm{b}}$ & $14.7 \pm 0.18^{\mathrm{b}}$ & $13.7 \pm 0.11^{\mathrm{ab}}$ & $20.2 \pm 0.18^{\mathrm{a}}$ & $43.3 \pm 0.33^{\mathrm{a}}$ \\
Cluster 2 & $42.6 \pm 0.24^{\mathrm{a}}$ & $14.7 \pm 0.19^{\mathrm{b}}$ & $14.3 \pm 0.1^{\mathrm{a}}$ & $20.5 \pm 0.18^{\mathrm{a}}$ & $44.4 \pm 0.34^{\mathrm{a}}$ \\
Cluster 3 & $33.7 \pm 0.38^{\mathrm{d}}$ & $13.1 \pm 0.42^{\mathrm{c}}$ & $10.0 \pm 0.33^{\mathrm{c}}$ & $16.4 \pm 0.52^{\mathrm{b}}$ & $37.3 \pm 0.46^{\mathrm{b}}$ \\
Cluster 4 & $37.3 \pm 0.23^{\mathrm{c}}$ & $16.4 \pm 0.23^{\mathrm{a}}$ & $13.0 \pm 0.14^{\mathrm{b}}$ & $20.9 \pm 0.24^{\mathrm{a}}$ & $38.7 \pm 0.32^{\mathrm{b}}$ \\
\hline
\end{tabular}

Breeds comprised in each cluster: (1) South Devon, Danish Red, Asturiana de los Valles, Pirenaica, Aberdeen Angus and Holstein breeds; (2) Limousin, Charolais, Piemontese and Marchigiana; (3) Jersey; (4) Simmental, Avileña-Negra Ibérica, Highland and Casina.

Different lowercase letter in the same column implies statistical differences between breeds $(P<0.05)$.

growth rates (Kempster et al., 1982; Warris, 2000). Figure 2 shows the hierarchical cluster analysis using the difference of colour $\left(\Delta \mathrm{E}^{*}\right)$ at $48 \mathrm{~h}$. The difference of colour measured grouped Jersey, Simmental, Avileña-Negra Ibérica, Highland and Casina together (Fig. 2) and the rest of the breeds formed a second group. Inside the first group, Jersey differed slightly from other breeds. The second group can be split into two subgroups with: Limousin, Charolais, Piemontese and Marchigiana in one, and the rest of the breeds in the other. To summarise, four clusters can be clearly defined according the similarity or dissimilarity of colour with one to six breeds in each (Table 4). Breeds could be clusters based on five colour traits and comprised (1) South Devon, Danish Red, Asturiana de los Valles, Pirenaica, Aberdeen Angus and Holstein breeds; (2) Limousin, Charolais, Piemontese and Marchigiana; (3) Jersey and (4) Simmental, AvileñaNegra Ibérica, Highland and Casina, with significant
Figure 2 Hierarchical cluster analysis using the difference of colour $\left(\Delta \mathrm{E}^{*}\right)$ at $48 \mathrm{~h}$ of cattle breeds.

Table 4 Differences between clusters in colour traits of longissimus thoracis muscle at $48 \mathrm{~h}$ post-mortem. Least square means \pm standard error are shown for four identified breed-clusters differences $(P<0.0001)$ between clusters. Cluster 3 was characterised by the lowest values of the five variables while Cluster 2 had the highest values of $\mathrm{L}^{*}$. Cluster 1 and 4 had intermediate values but Cluster 1 had higher values for $\mathrm{L}^{*}$ and $h_{a b}$ than Cluster 4. Therefore, the meat of these clusters could be defined as 'dark and dull red', 'bright and pale', 'red' and 'very bright and pale-red' for clusters 3, 1, 4 and 2, respectively. We want to point out that names of these clusters are based strictly in the colorimetric variables (Paterson, 2004).

Meat colour can be influenced by intramuscular fat content, as well as fibre type (Cuvelier et al., 2006), which are both affected by muscle development (Bernard et al., 2009; Hocquette et al., 2012). In general, the higher the muscularity, the paler the meat colour and lower the intramuscular fat content. This is especially true for double-muscled animals, which carry a mutation in their myostatin gene, and are 
characterised by a higher proportion of white muscle fibres (Fiems et al., 2003) and consequently, higher muscle glycolytic activity than normal animals (Gil et al., 2001; Oliván et al., 2004). However, differences in meat colour are also observed between different genetic types, which do not have a mutation in the myostatin gene. Divergent genetic selection for muscle growth potential e.g. between meat, dairy and dual purpose breeds also results in differences in muscle fibre types and IMF content (Hocquette et al., 2012). This is in part due to differentially expressed genes associated either with muscle mass or fat deposition in the carcass (Bernard et al., 2009).

Specialised beef breeds are generally late-maturing and fatten later than unimproved and dairy breeds (Albertí et al., 2005; Boligon et al., 2016). However, the variation in meat colour observed the present study is not related to fatness as assessed by intramuscular fat deposition (Christensen et al., 2011) or the dissected rib fat content (Albertí et al., 2008). Indeed, Piemontese and Charolais have a pale-red colour but Piemontese was the leanest breed and Charolais had intermediate levels of fat. Furthermore, Holstein, Danish Red, Aberdeen Angus and South Devon breeds had bright-red meat colour with a relative high fat levels, while Pirenaica and Asturiana de los Valles breeds with low fat depots also had bright red meat. If breeds are grouped according to body size and carcass traits (Albertí et al., 2008), the Piemontese, Asturiana de los Valles, Pirenaica, Limousin, South Devon, Charolais and Aberdeen Angus can be considered as specialised beef breeds, Avileña, Marchigiana and Simmental as intermediate or dual purpose breeds and Casina, Highland, Danish Red, Jersey and Holstein as unimproved and dairy breeds. Classification of breeds by colour or carcass traits gives quite similar groupings. In general, the specialised beef breeds have pale-red to bright-red lean meat colour but the Marchigiana had a pale-red colour while the Holstein and Danish Red had a bright-red colour. Muscle structure and fibres of the experimental animals have previously been characterised by their metabolic and contractile properties (Hocquette et al., 2007). These analyses revealed significant differences among breeds. Generally, dairy breeds and unimproved breeds had a high muscle oxidative metabolism as shown by high cytochrome- $c$ oxidase (COX), citrate synthase (CS) or isocitrate dehydrogenase (ICDH) activities, which are generally associated with a high proportion of myosin heavy chain (MyHC)-I. High muscling and lean breeds, however, had the highest proportions of myosin heavy chain (MyHC) fast-glycolytic fibres (IIX) and the most glycolytic metabolism, as indicated by lactate dehydrogenase (LDH) activity. Usually the oxidative fibre characteristics (MyHC-I, ICDH, COX and CS) are negatively associated with glycolytic characteristics (MyHC-IIx and LDH) (Gagaoua et al., 2016). The red colour meat of Avileña and Casina and dark red of Jersey may be related to a high COX activity in muscle fibres (Cuvelier et al., 2006), in contrast Piemontese, with a high glycolytic metabolism, had a pale meat colour. These results are in agreement with the observations of other authors: Cuvelier et al. (2006) found that Aberdeen Angus had a low $\mathrm{L}^{*}$ value associated with a low LDH metabolic activity and Blue Belgian bulls had light and pale meat due to their low mitochondrial enzyme activity (COX), whereas Limousin had intermediate characteristics. The light pale meat colour of the meat from Asturiana and Pirenaica may be related to a high proportion of IIA muscle fibres, of the fast-twitch oxidative-glycolytic type, and high glycolytic capacity (LDH/ICDH ratio) (Gil et al. (2001).

Genetic variation is likely to contribute substantially to animal-to-animal variation in lean meat colour (King et al., 2010). Molecular markers for meat quality have been analysed for the fifteen breeds studied here (Dunner et al., 2013). Two single nucleotide polymorphism (SNP) in PGAM2 were associated with $\mathrm{L}^{*}$ and $\mathrm{b}^{*}$. PGAM2 catalyses the internal transfer of a phosphate group in the glycolysis process and it affects the activity of COX in muscle. Simmental, Limousin and Charolais have the highest frequency of the PGAM2 SNP associated with high COX activity (allele frequency: $1.00,0.95$ and 0.94 ), respectively, while Holstein had the lowest frequency (0.56). A SNP in the myofibrillar protein vimentin (VIM) gene, was associated with $\mathrm{L}^{*}$ and $\mathrm{b}^{*}$ at 10 days (Dunner et al., 2013). Limousin and Pirenaica has the same highest frequency of the VIM SNP (0.88) while Holstein and Jersey had the lowest frequency $(0.37$ and 0.34 , respectively) of the same SNP. Therefore, the differences found in the colour of the meat between breeds could have a genetic basis associated with contractile and metabolic characteristics of muscle fibres.

\section{Conclusions}

The present study shows that lean meat colour differs significantly between the fifteen European cattle breeds investigated. These breeds can be grouped according to four scales of commercial interest: very bright and pale-red (Limousin, Charolais, Piemontese and Marchigiana), bright and pale (South Devon, Danish Red, Asturiana de los Valles, Pirenaica, Aberdeen Angus and Holstein), red (Simmental, Avileña-Negra Ibérica, Highland and Casina) and dark and dull red (Jersey). The differentiation between groups approximately correlate with body size and carcass traits, particularly fatness and muscle development and structure, and hence selection history of the breeds. 
Therefore, the purpose of the breeds is related to the colour of the meat. The most specialised beef breeds had very bright and pale-red. Another beef breeds together with some dairy breeds had bright and pale meat. The intermediate beef breeds and dual-purpose breeds had red meat, and Jersey as a small dairy cattle had dull red meat.

\section{Acknowledgments}

This work was supported by the EU Commission Sixth Framework Programme Project 'GemQual' (QLK5-CT-2000-0147). The authors acknowledge the staff of the different experimental stations and abattoirs that were involved in rearing and slaughtering of the animals.

\section{Conflict of interest}

The authors declare that they have no conflict of interest.

\section{Compliance with ethical standards}

All procedures were approved by the in-house Ethics Committee for Animal Experiments of each participating research centres.

\section{References}

Albertí, P., Ripoll, G., Goyache, F. et al. (2005). Carcass characterisation of seven Spanish beef breeds slaughtered at two commercial weights. Meat Science, 71, 514-521.

Albertí, P., Panea, B., Sañudo, C. et al. (2008). Live weight, body size and carcass characteristics of young bulls of fifteen European breeds. Livestock Science, 114, 19-30.

Albertí, P., Ripoll, G., Albertí, C. \& Panea, B. (2017). Etude de la couleur des différents types de viande bovine vendus en Espagne. Viandes et producits carnés, 33, 1-9.

AMSA (2012). Guidelines for Meat Color Evaluation. Pp. 124. Champaign, IL, USA: American Meat Science Association.

Barahona, M., Olleta, J.L., Sanudo, C. et al. (2016). Effects of whole linseed and rumen-protected conjugated linoleic acid enriched diets on beef quality. Animal, 10, 709-717.

Bernard, C., Cassar-Malek, I., Renand, G. \& Hocquette, J.-F. (2009). Changes in muscle gene expression related to metabolism according to growth potential in young bulls. Meat Science, 82, 205-212.

Boligon, A.A., Vicente, I.S., Vaz, R.Z. et al. (2016). Principal component analysis of breeding values for growth and reproductive traits and genetic association with adult size in beef cattle1. Journal of Animal Science, 94, 5014-5022.

Bonny, S., Pethick, D., Legrand, I. et al. (2016). European conformation and fat scores have no relationship with eating quality. Animal, 10, 996-1006.

Chambaz, A., Scheeder, M., Kreuzer, M. \& Dufey, P.-A. (2003). Meat quality of Angus, Simmental, Charolais and Limousin steers compared at the same intramuscular fat content. Meat Science, 63, 491-500.

Christensen, M., Ertbjerg, P., Failla, S. et al. (2011). Relationship between collagen characteristics, lipid content and raw and cooked texture of meat from young bulls of fifteen European breeds. Meat Science, 87, 61-65.

CIE (1986). Colorimetry. Vienna: Centre International de L'eclairage.

Corcoran, K., Bernués, A., Manrique, E., Pacchioli, M.T., Baines,

R. \& Boutonnet, J.P. (2001). Current consumer attitudes towards lamb and beef in Europe. Options méditerranéennes, A46, 75-79.

Cuvelier, C., Clinquart, A., Hocquette, J.F. et al. (2006). Comparison of composition and quality traits of meat from young finishing bulls from Belgian Blue, Limousin and Aberdeen Angus breeds. Meat Science, 74, 522-531.

Dunner, S., Sevane, N., García, D. et al. (2013). Association of genes involved in carcass and meat quality traits in 15 European bovine breeds. Livestock Science, 154, 34-44.

E.U. (2000). Regulation (EC) No 1760/2000 of the European parliament and of the Council of 17 July 2000 establishing a system for the identification and registration of bovine animals and regarding the labelling of beef and beef productsand repealing Council Regulation (EC) No 820/97. In: Official Journal of the European Communities. Pp. L204/1-L204/10.

E.U. (2008). Commission Regulation (EC) No 1429/2008 of 10 December 2008 laying down detailed rules on the implementation of the Community scales for the classification of beef, pig and sheep carcases and the reporting of prices thereof. In: Off. J. Eur. Union L.

E.U. (2010). Directive 2010/63/EU of the European Parliament and of the Council of 22 September 2010 on the protection of animals used for scientific purposes. In: Official Journal of the European Communities. L276. Pp. 33-79.

Fiems, L.O., De Campeneere, S., Van Caelenbergh, W., De Boever, J.L. \& Vanacker, J.M. (2003). Carcass and meat quality in double-muscled Belgian Blue bulls and cows. Meat Science, 63, 345-352.

Gagaoua, M., Terlouw, E., Micol, D. et al. (2016). Sensory quality of meat from eight different types of cattle in relation with their biochemical characteristics. Journal of Integrative Agriculture, 15, $1550-1563$.

Gil, M., Serra, X., Gispert, M. et al. (2001). The effect of breedproduction systems on the myosin heavy chain 1 , the biochemical characteristics and the colour variables of Longissimus thoracis from seven Spanish beef cattle breeds. Meat Science, 58, 181188.

Hocquette, J.F., Lehnert, S., Barendse, W., Cassar-Malek, I. \& Picard, B. (2007). Recent advances in cattle functional genomics and their application to beef quality. Animal, 1, 159-173.

Hocquette, J.-F., Botreau, R., Picard, B., Jacquet, A., Pethick, D.W. \& Scollan, N.D. (2012). Opportunities for predicting and manipulating beef quality. Meat Science, 92, 197-209.

Kempster, T., Cuthberston, A. \& Harrington, G. (1982). Carcase Evaluation in Livestock Breeding, Production and Marketing. Pp. 306. London: Granada Publishing Limited.

King, D., Shackelford, S., Kuehn, L. et al. (2010). Contribution of genetic influences to animal-to-animal variation in myoglobin content and beef lean color stability. Journal of Animal Science, 88, $1160-1167$.

Klont, R.E., Barnier, V.M.H., Smulders, F.J.M., Van Dijk, A., Hoving-Bolink, A.H. \& Eikelenboom, G. (1999). Post-mortem variation in $\mathrm{pH}$, temperature, and colour profiles of veal carcasses in relation to breed, blood haemoglobin content, and carcass characteristics. Meat Science, 53, 195-202.

Lynch, N.M., Kastner, C.L. \& Kropf, D.H. (1986). Consumer acceptance of vacuum packaged ground beef as influenced by product color and educational materials. Journal of Food Science, 51, 253-255.

MacDougall, D.B. (1982). Changes in the colour and opacity of meat. Food Chemistry, 9, 74-88.

Mach, N., Bach, A., Velarde, A. \& Devant, M. (2008). Association between animal, transportation, slaughterhouse practices, and meat $\mathrm{pH}$ in beef. Meat Science, 78, 232-238. 
Maher, S.C., Mullen, A.M., Moloney, A.P., Drennan, M.J., Buckley, D.J. \& Kerry, J.P. (2004). Colour, composition and eating quality of beef from the progeny of two Charolais sires. Meat Science, 67, 73-80.

Mancini, R.A. \& Hunt, M.C. (2005). Current research in meat color. Meat Science, 71, 100-121.

Miranda-de la Lama, G.C., Pascual-Alonso, M., Guerrero, A. et al. (2013). Influence of social dominance on production, welfare and the quality of meat from beef bulls. Meat Science, 94, 432-437.

Monteils, V., Sibra, C., Ellies-Oury, M.P., Botreau, R., De la Torre, A. \& Laurent, C. (2017). A set of indicators to better characterize beef carcasses at the slaughterhouse level in addition to the EUROP system. Livestock Science, 202, 44-51.

Oliván, M., Martínez, A., Osoro, K. et al. (2004). Effect of muscular hypertrophy on physico-chemical, biochemical and texture traits of meat from yearling bulls. Meat Science, 68, 567-575.

Panea, B., Albertí, P., Olleta, J.L. et al. (2008). Intrabreed variability and relationships for 41 carcass and meat traits in Pirenaica cattle. Spanish Journal of Agricultural Research, 6, 546-558.
Paterson, I. (2004). A Dictionary of Colour. Pp. 528. London, UK: Thorogood Publishing Ltd.

Renand, G., Picard, B., Touraille, C., Berge, P. \& Lepetit, J. (2001). Relationships between muscle characteristics and meat quality traits of young Charolais bulls. Meat Science, 59, 49-60.

Ripoll, G., Panea, B. \& Albertí, P. (2012). Visual appraisal of beef: relationship with CIELab colour space. ITEA-Informacion Tecnica Economica Agraria, 108, 222-232.

Serra, X., Gil, M., Gispert, M. et al. (2004). Characterisation of young bulls of the Bruna dels Pirineus cattle breed (selected from old Brown Swiss) in relation to carcass, meat quality and biochemical traits. Meat Science, 66, 425-436.

Taylor, S.A. (1996). Modified atmosphere packaging of meat. In: Meat Quality and Meat Packaging (edited by S.A. Taylor, A. Raimundo, M. Severini\& F.J. Smulders). Pp. 301-3011. Utrecht, The Netherlands: ECCEAMST, III.

Warris, P. (2000). Meat Science. An Introductory Text. Pp. 310. New York, NY, USA: CABI Publishing. 